\title{
Experimental Study on the Mechanical Properties of Construction Waste Recycled Aggregate Concrete
}

\author{
Tian Xiao1, a, Ji shu Sun ${ }^{2, ~ b}$, Xiao hua Wang ${ }^{1}$ \\ ${ }^{1}$ Tianjin Municipal Engineering Design \& Research Institute, No. 30 Haitai South Road, Nankai \\ District, Tianjin, 300392, China \\ ${ }^{2}$ School of Civil and Transportation Engineering, Hebei University of Technology, No. 5340 Xiping \\ Road, Beichen District, Tianjin, 300401, China \\ axiaotian95@126.com, bsunjishu76@126.com
}

\begin{abstract}
Keywords: Concrete, Compressive Strength, Recycled Aggregate, Construction Waste, Experimental Study

Abstract. In order to investigate the application technology using construction waste to product recycled aggregate concrete, the effect law of recycled aggregate content and brick content in the recycled aggregate on mechanical properties of recycled aggregate concrete, include compressive strength and flexural strength, were studied through experiments. The results indicate that the compressive strength and flexural strength of recycled aggregate concrete would decrease with the recycled aggregate content increased. The mechanical properties of recycled aggregate concrete would decrease with the brick content increased on the same recycled aggregate content. So the brick content in the recycled aggregate should be controlled within $50 \%$.
\end{abstract}

\section{Introduction}

At present, China is in the high-speed development stage of urbanization, the expansion of the city makes a large number of demolishing old buildings and building new construction projects every year. The construction waste resulting from the demolition of old buildings and other projects is increased year by year. The construction waste would increase more than 3 billion tons every year in China [1]. However, the utilization rate of construction waste is very low. The effective utilization rate is only about 5\%, far below the level of developed countries [2]. In order to make further use of construction waste, the majority of scientific and technological workers have done a lot of research work. Through experiments, Han Ruimin and others studied the design method of mix proportion of the construction waste used in the highway pavement base material with inorganic matrix as binder [3]. Li Zhenxing et al. analyzed the technical performance of recycled aggregate from different primary concrete [4]. Through the test, Sun Jishu et al. studied the mechanical properties of recycled cement concrete pavement [5]. Jia Shuming used the construction waste concrete as raw material which from a site in Lanzhou to prepare recycled coarse aggregate and studied the compressive strength of recycled concrete with construction waste as aggregate [6]. These research achievements can be some references for the application of construction waste. In the research on the preparation of recycled concrete with construction waste as raw material, the waste concrete is used to prepare coarse and fine aggregate [4-8]. However, the composition of construction waste is mainly waste concrete and waste brick. It is difficult to separate the waste bricks in construction waste.

The mechanical properties of recycled coarse aggregate concrete with waste concrete and waste brick as raw materials were studied systematically in this paper. And the influence of different waste brick contents on the mechanical properties of recycled concrete was studied, too. These research achievements can provide us with some guidance to improve the effective utilization of construction waste.

\section{Properties of raw material}

Cement. The cement used in the experiments is P.O.32.5 cement. The technical properties of the cement were shown in Table 1. 
Table 1 The Technical properties of the cement

\begin{tabular}{|c|c|c|c|c|c|c|}
\hline \multirow{2}{*}{ Items } & \multirow{2}{*}{ Fineness } & \multirow{2}{*}{$\begin{array}{c}\text { Normal } \\
\text { Consistency }\end{array}$} & \multicolumn{2}{|c|}{ Folding Strength } & \multicolumn{2}{c|}{ Compressive Strength } \\
\cline { 4 - 7 } & & $26.2 \%$ & $4.5 \mathrm{MPa}$ & $6.5 \mathrm{MPa}$ & $18.7 \mathrm{MPa}$ & $37.6 \mathrm{MPa}$ \\
\hline Test Results & $5.0 \%$ & $28 \mathrm{~d}$ & $\mathrm{~d}$ & $\mathrm{M}$ & $\mathrm{M}$ & $\mathrm{M}$ \\
\hline
\end{tabular}

Coarse aggregate. The construction waste used in this paper was from the site of the Tianjin Convention and Exhibition Center. The strength of waste brick reached MU15. After artificial classification, crushing, screening, cleaning, waste concrete recycled coarse aggregate and waste brick recycled coarse aggregate are obtained respectively. The new coarse aggregate is made of crushed limestone. The main physical and mechanical properties of recycled coarse aggregate and new coarse aggregate were tested and shown in Table 2.

Table 2 The Physical properties of coarse aggregates

\begin{tabular}{|c|c|c|c|}
\hline Aggregate Type & $\begin{array}{c}\text { Crushing } \\
\text { Value [\%] }\end{array}$ & $\begin{array}{c}\text { Robustness } \\
{[\%]}\end{array}$ & $\begin{array}{c}\text { Los Angeles } \\
\text { Abrasion Value[\%] }\end{array}$ \\
\hline $\begin{array}{c}\text { Recycled Waste } \\
\text { Concrete Aggregate }\end{array}$ & 19.1 & 12.1 & 22.3 \\
\hline $\begin{array}{c}\text { Recycled Waste } \\
\text { Brick Aggregate }\end{array}$ & 27.2 & 16.8 & 28.2 \\
\hline New Aggregate & 12.6 & 8.1 & 17.2 \\
\hline
\end{tabular}

Test results from Table 2 indicate that the recycled aggregate of waste concrete can meet the requirements of second-class gravel [9]. But the crushing value and los angeles abrasion value of recycled waste brick aggregate are too large for the preparation of structural concrete separately.

Fine aggregate. The natural river sand was used as fine aggregate. Its silt content less than $1.9 \%$ and its fineness modulus is 2.2 .

\section{Test Set-up}

Mix Proportion of Recycled Aggregate Concrete. The effect law of recycled aggregate content and the ratio of waste brick and waste concrete in the recycled aggregate on mechanical properties of recycled aggregate concrete were emphatically studied in this paper. The target proportioning was selected as C25. Reference to the general method and specification of concrete mix design [10], based on the preliminary test, the mix proportion of recycled aggregate concrete was determined as follow: (1) Selected the ratio of waste brick and waste concrete in the recycled aggregate as 1:4, the amount of recycled aggregate in the coarse aggregate was $0,25 \%, 50 \%, 75 \%, 100 \%$ respectively; (2) Coarse aggregate is all the recycled aggregate and the proportion of recycled waste brick aggregate is $0,25 \%$, $50 \%, 100 \%$, respectively. Mix proportion of recycled aggregate concrete was shown in Table 3.

Table 3 Mix proportion of recycled aggregate concrete

\begin{tabular}{|c|c|c|c|c|c|c|}
\hline \multirow{2}{*}{$\begin{array}{c}\text { Item } \\
\text { Number }\end{array}$} & \multirow{2}{*}{$\begin{array}{c}\text { Cement } \\
{[\mathbf{k g}]}\end{array}$} & \multirow{2}{*}{$\begin{array}{c}\text { Water } \\
{[\mathbf{k g}]}\end{array}$} & $\begin{array}{c}\text { Fggregate } \\
\text { Akg] }\end{array}$ & $\begin{array}{c}\text { New Coarse } \\
\text { Aggregate } \\
{[\mathbf{k g}]}\end{array}$ & \multicolumn{2}{|c|}{$\begin{array}{c}\text { Recycled Coarse Aggregate } \\
{[\mathbf{k g}]}\end{array}$} \\
\cline { 6 - 7 } & & & Waste Brick & Waste Concrete \\
\hline A-0 & 381 & 202 & 608 & 1256 & 0 & 0 \\
\hline A-25 & 381 & 215 & 608 & 942 & 79 & 235 \\
\hline A-50 & 381 & 229 & 608 & 628 & 157 & 471 \\
\hline A-75 & 381 & 246 & 608 & 314 & 235 & 707 \\
\hline A-100(B-25) & 381 & 262 & 608 & 0 & 314 & 942 \\
\hline B-0 & 381 & 250 & 608 & 0 & 0 & 1256 \\
\hline B-50 & 381 & 275 & 608 & 0 & 628 & 628 \\
\hline B-75 & 381 & 290 & 608 & 0 & 942 & 314 \\
\hline B-100 & 381 & 303 & 608 & 0 & 1256 & 0 \\
\hline
\end{tabular}

Test Specimen. The size of specimen for compressive strength tests and flexural strength tests were selected as $150 \mathrm{~mm} \times 150 \mathrm{~mm} \times 150 \mathrm{~mm}$ and $150 \mathrm{~mm} \times 150 \mathrm{~mm} \times 550 \mathrm{~mm}$. 


\section{Test Results and Analysis}

The Compressive Strength. According to the standard method [10], the 7-day and 28-day compressive strength of recycled concrete with different recycled coarse aggregate content in case of waste brick and waste concrete ratio of 1:4 were were tested. The results were shown in Table 4 .

Table 4 Compressive strength of recycled concrete with different recycled aggregate content

\begin{tabular}{|c|c|c|c|}
\hline \multirow{2}{\text{Item}}{$\begin{array}{c}\text { Recycled aggregate } \\
\text { content [\%] }\end{array}$} & \multicolumn{2}{|c|}{ Compressive strength [MPa] } \\
\cline { 3 - 4 } & 0 & 7 -day & 28 -day \\
\hline A-0 & 25 & 23.6 & 36.9 \\
\hline A-25 & 50 & 23.2 & 35.2 \\
\hline A-50 & 75 & 22.5 & 33.6 \\
\hline A-75 & 100 & 21.1 & 31.5 \\
\hline A-100 & 19.3 & 28.5 \\
\hline
\end{tabular}

It can be seen from Table 3 that the compressive strength of recycled aggregate concrete in the test can meet the requirements of $\mathrm{C} 25$. At the same time, the compressive strength of recycled aggregate concrete would decrease with the increase of recycled coarse aggregate content. When the amount of recycled coarse aggregate was 25\%, 50\%, 75\% and 100\%, the 7-day and 28-day compressive strength of recycled aggregate concrete decreased by $1.7 \%, 4.7 \%, 10.6 \%, 18.2 \%$ and $4.6 \%, 8.9 \%$, $14.6 \%, 22.8 \%$, respectively. The reduction in the compressive strength of the recycled coarse aggregate is mainly due to the fact that recycled aggregate will inevitably stick some cement mortar, and this lead to the bond between the recycled aggregate and the cement mortar to be relatively weak. In addition, the effect of recycled coarse aggregate content on the compressive strength of concrete is weaker in the early stage. The relationship between compressive strength and recycled coarse aggregate content was shown in Figure 1.

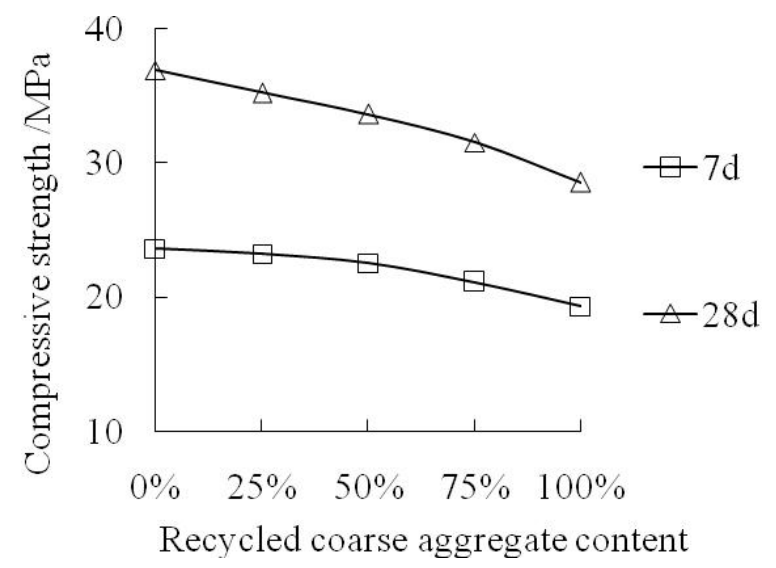

Fig. 1 Relationship between compressive strength and recycled coarse aggregate content

As can be seen from Figure 1, when the content of recycled coarse aggregate is greater than 50\%, the compressive strength of recycled concrete increases significantly with the increase of recycled coarse aggregate. Therefore, the amount of recycled coarse aggregate in the recycled concrete should not be greater than $50 \%$.

When the amount of recycled coarse aggregate is $100 \%$, the compressive strength of recycled aggregate concrete under different recycled brick coarse aggregate content is shown in Table 5. 
Table 5 Compressive strength of recycled concrete with different recycled brick coarse aggregate content

\begin{tabular}{|c|c|c|c|}
\hline \multirow{2}{*}{ Item Number } & \multirow{2}{*}{$\begin{array}{l}\text { Recycled waste brick } \\
\text { aggregate content [\%] }\end{array}$} & \multicolumn{2}{|c|}{ Compressive strength $[\mathrm{MPa}]$} \\
\hline & & 7-day & 28-day \\
\hline B-0 & 0 & 20.3 & 30.2 \\
\hline B-25 & 25 & 19.5 & 28.7 \\
\hline B-50 & 50 & 18.3 & 27.1 \\
\hline B-75 & 75 & 17.2 & 24.9 \\
\hline B-100 & 100 & 15.7 & 22.6 \\
\hline
\end{tabular}

The test results of show that the compressive strength of recycled aggregate concrete would decrease with the increase of recycled waste brick aggregate. When the amount of recycled waste brick aggregate was $25 \%, 50 \%, 75 \%$ and $100 \%$, the 7 -day and 28-day compressive strength of recycled concrete decreased by $3.9 \%, 9.9 \%, 15.3 \%, 22.7 \%$ and $4.9 \%, 10.2 \%, 17.5 \%, 25.2 \%$, respectively. When the recycled waste brick coarse aggregate content reached $75 \%$, the 28 -day compressive strength of recycled aggregate concrete was $99.6 \%$ of the design strength, which could not meet the requirements. When the recycled brick coarse aggregate content reached $50 \%$, the 28-day compressive strength of recycled aggregate concrete was $108 \%$ of the design strength, respectively. Therefore, the amount of recycled waste brick coarse aggregate should be controlled within $50 \%$.

The Flexural Strength. According to the standard method [10], the flexural strength of recycled aggregate concrete with different mixing ratio is measured. The results are shown in Table 6.

Table 6 Flexural strength of recycled aggregate concrete

\begin{tabular}{|c|c|c|c|c|c|c|c|}
\hline \multirow{2}{*}{$\begin{array}{c}\text { Item } \\
\text { Number }\end{array}$} & \multirow{2}{*}{$\begin{array}{c}\text { Recycled } \\
\text { aggregate } \\
\text { content [\%] }\end{array}$} & \multicolumn{2}{|c|}{$\begin{array}{c}\text { Compressive } \\
\text { strength [MPa] }\end{array}$} & \multirow{2}{*}{$\begin{array}{c}\text { Item } \\
\text { Number }\end{array}$} & $\begin{array}{c}\text { Recycled waste } \\
\text { brick aggregate } \\
\text { content [\%] }\end{array}$ & \multicolumn{2}{c|}{$\begin{array}{c}\text { Compressive } \\
\text { strength [MPa] }\end{array}$} \\
& & 28 -day & & 7-day & 28-day \\
\hline A-0 & 0 & 2.97 & 4.41 & B-0 & 0 & 2.47 & 3.57 \\
\hline A-25 & 25 & 2.91 & 4.09 & B-25 & 25 & 2.41 & 3.35 \\
\hline A-50 & 50 & 2.85 & 3.87 & B-50 & 50 & 2.21 & 3.18 \\
\hline A-75 & 75 & 2.72 & 3.76 & B-75 & 75 & 2.06 & 2.91 \\
\hline A-100 & 100 & 2.41 & 3.35 & B-100 & 100 & 1.89 & 2.67 \\
\hline
\end{tabular}

Test results indicate that the flexural strength of recycled aggregate concrete would decrease with the increase of the amount of recycled coarse aggregate. Relative to ordinary concrete, when the amount of recycled coarse aggregate was $25 \%, 50 \%, 75 \%$ and $100 \%$, the 28 -day flexural strength of recycled aggregate concrete decreased by $7.2 \%, 12.2 \%, 14.7 \%, 24.0 \%$. When the amount of recycled coarse aggregate is $100 \%$, the flexural strength of recycled concrete would decrease with the increase of the recycled waste brick aggregate content. The flexural strength of recycled concrete decreased by $6.2 \%, 10.9 \%, 18.5 \%$ and $25.2 \%$ respectively, when the amount of recycled waste brick coarse aggregate was $25 \%, 50 \%, 75 \%$ and $100 \%$. The test results show that the amount of recycled waste brick coarse aggregate in recycled concrete should not be too much. Its content should be controlled within $50 \%$.

\section{Conclusions}

Through systematic experiments, the effect law of recycled aggregate content and brick content in the recycled aggregate on mechanical properties of recycled aggregate concrete were studied. The main conclusions obtained are summarized below.

(1) The compressive strength, flexural strength of recycled concrete would decrease with the increase of the amount of recycled coarse aggregate. The 28-day compressive strength, flexural strength decreased by $4.6 \%, 8.9 \%, 14.6 \%, 22.8 \%$ and $7.2 \%, 12.2 \%, 14.7 \%, 24.0 \%$ respectively when the amount of recycled coarse aggregate is $25 \%, 50 \%, 75 \%$ and $100 \%$.

(2) The compressive strength, flexural strength of recycled concrete would decrease with the increase of the recycled waste brick coarse aggregate content. When the amount of recycled brick 
coarse aggregate was $25 \%, 50 \%, 75 \%$ and $100 \%$, the 28 -day compressive strength, flexural strength and elastic modulus of recycled concrete decreased by $4.9 \%, 10.3 \%, 17.5 \%, 25.1 \%$ and $6.2 \%, 10.9 \%$, $18.5 \%, 25.2 \%$ respectively.

(3) When the content of recycled coarse aggregate is greater than $50 \%$, the compressive strength of recycled concrete decreases significantly with the increase of recycled coarse aggregate. Therefore, the amount of recycled coarse aggregate should not be greater than $50 \%$. At the same time, the content of recycled waste brick coarse aggregate should be controlled within $50 \%$.

\section{References}

[1] SHI Feng, NING Lizhong and LIU Xiaofeng et al. "Comprehensive utilization of architectural solid waste". Chinese Journal of Water Resources and Water Engineering, Vol. 18 (2007):39-42 (in Chinese).

[2] LI Lei, ZHANG Gangtai, QIN Yongjun. "Study on comprehensive utilization of municipal construction waste in Urumchi", Chinese Journal of Sichuan Building Science, Vol. 39 (2013):370-372 (in Chinese).

[3] HAN Ruimin, QI Feng, ZHANG Mingcheng. "Study on mix proportion design and performance test of construction waste recycled mixture". Chinese Journal of Highway, Vol. 3 (2014):185-188 (in Chinese).

[4] LI Zhenxing, QIN Yongjun, YOU Biao, et al. "Research on the properties of different parent recycled concrete fine aggregates", Chinese Journal of Concrete, Vol. 4 (2014):93-96 (in Chinese).

[5] SUN Jishu, XIAO Chengzhi, DOU Yuanming. "Experimental study on mechanical properties of recycled concrete with waste concrete pavement", Chinese Journal of Concrete, Vol. 2 (2013):85-86 (in Chinese).

[6] JIA Shuming, WANG Jianjun, ZHAO Yonghua, et al. "Construction waste recycled concrete aggregate performance study", Chinese Journal of Construction Technology, Vol. 43 (2014):165-168 (in Chinese).

[7] HOU Yueqin, JI Xiaoping, ZHANG Wengang, et al. "Research on performances of asphalt treated base containing", Chinese Journal of Wuhan University of Technology, Vol. 35 (2013):60-64 (in Chinese).

[8] SHI Yihai. "Feasibility analysis of recycling waste concrete", Chinese Journal of Sichuan Building Science, Vol. 35 (2009):241-243 (in Chinese).

[9] Ministry of Communication. "Specification for aggregate test of Highway Engineering". China Communication Press, JTG E42-2005 (in Chinese).

[10] Ministry of construction. "Standard test method for mechanical properties of ordinary concrete". China Building Industry Press, GB/T50081-2002 (in Chinese). 